Article

\title{
Bio-Waste Aloe vera Leaves as an Efficient Adsorbent for Titan Yellow from Wastewater: Structuring of a Novel Adsorbent Using Plackett-Burman Factorial Design
}

\author{
Marwa El-Azazy *(D), Sarra N. Dimassi, Ahmed S. El-Shafie $\mathbb{D}$ and Ahmed A. Issa \\ Department of Chemistry and Earth Sciences, College of Arts and Sciences, Qatar University, Doha 2713, \\ Qatar; sd1510450@qu.edu.qa (S.N.D.); aelshafie@qu.edu.qa (A.S.E.-S.); ahmedissa@qu.edu.qa (A.A.I.) \\ * Correspondence: marwasaid@qu.edu.qa; Tel.: +974-4403-4675; Fax: +974-4403-4651
}

Received: 16 October 2019; Accepted: 6 November 2019; Published: 13 November 2019

\begin{abstract}
Titan yellow (TY), a triazene azo dye, was removed from contaminated wastewater samples using a green adsorbent recycled from Aloe vera leaves (AV) waste. Two adsorbents were developed-air-dried Aloe vera (ADAV) and thermally treated Aloe vera (TTAV). Adsorption efficacy of both adsorbents was assessed in terms of percent removal (\%R) of TY and adsorption capacity $\left(q_{e}\right)$. ADAV had a better performance compared to TTAV. Plackett-Burman design (PBD) was exploited to establish the experimental pattern of the study. Four variables were studied: $\mathrm{pH}$, adsorbent dose (AD), dye concentration (DC), and stirring time (ST). Analysis of variance (ANOVA) at 95.0 confidence interval (CI), control, and quality charts helped establish regression model(s). Characterization of both adsorbents was performed using FT-IR/Raman spectroscopy together with TGA/dTGA and SEM/energy dispersive X-ray spectroscopy (EDX) analyses. Textural properties were determined using nitrogen adsorption isotherms at $77 \mathrm{~K}$. Results showed that the surface areas of ADAV and TTAV300 were 3.940 and $7.076 \mathrm{~m}^{2} / \mathrm{g}$, respectively. Raman analysis showed that the TTAV had clear Dand G-bands. Equilibrium studies revealed that data were well fitted to Freundlich isotherm with a maximum adsorption capacity of $55.25 \mathrm{mg} / \mathrm{g}$ using Langmuir equation, and the adsorption was physisorption. Adsorption followed a pseudo-second order that occurred in two steps-diffusion and then adsorption.
\end{abstract}

Keywords: Aloe vera (AV) leaves; Plackett-Burman Design (PBD); Titan yellow (TY); \%removal and adsorption capacity $\left(q_{e}\right)$; characterization; equilibrium; kinetics

\section{Introduction}

Water has ever been the most significant life component for all creatures. With the notable rise in global warming and desertification, water quantity is becoming a worldwide concern [1,2]. While the quantity of water and the share per capita are growing apprehensions, quality of water, which is relapsing progressively-mostly because of the anthropogenic deeds, the population development, the inadvertent expansion, the swift industrialization, and the inappropriate usage of natural water-is becoming a more serious concern [3].

Food, leather, and textile industries release large amounts of contaminated effluents. With the diverse chemical structure of the reagents used in these industries, various problems evolve. Dyes, an example of a major water contaminant, would color large volumes of water even if released as traces as low as $1 \mathrm{ppm}$. This effect causes not only an undesirable change in water quality in terms of aesthetic properties, but also it cannot be easily reversed or "decolorized". Reports show that, with the huge amount of dyes being produced annually $\left(7 \times 10^{5}\right.$ tons/annum), an amount of $2 \%$ of dyes is directly 
released into the aquatic system together with an amount of $10 \%$ being lost during the tanning process, an issue that signifies the magnitude of the problem [4-6]. Released dyes affect not only aquatic beings but also human health. Their impacts include carcinogenicity, mutagenicity, poisoning, disturbance of the metabolism in aquatic bodies, etc. [7,8].

Titan yellow (TY, Figure 1) is an organic triazene azo dye commonly used in tanning nylon and wool as well as a stain in microscopical examinations. The safety data sheet of TY shows that it is hazardous in case of ingestion with a less hazardous influence on eyes and skin $[9,10]$.

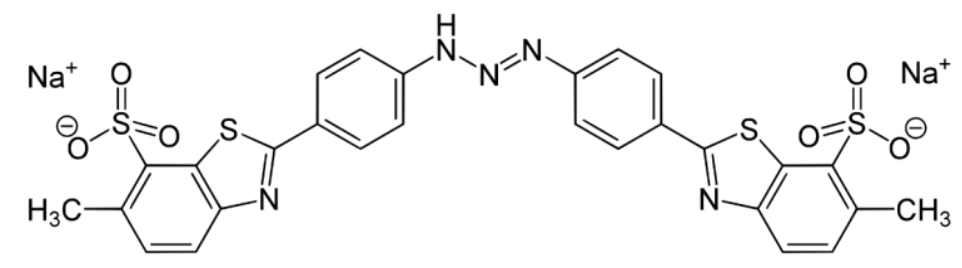

Figure 1. Structure of Titan yellow (TY).

Removal of dyes from wastewater has been done by employing several approaches, e.g., adsorption, bleaching, filtration, biodegradation, and coagulation [11]. These methods possess both pros and cons in terms of cost, availability, efficacy, and surface area and have different influences on the environment. Adsorption, with the capability to totally remove dyes from wastewater, represents an ideal approach. Modeling of an efficient, green, low cost, safe, and reusable adsorbent (in other words, a standard adsorbent) has been the subject of various investigations. While different adsorbents have been used to remove dyes, the most commonly used adsorbents are the activated carbon (char) [12,13].

As developing a standard adsorbent has been the task undertaken in many investigations, a novel category of adsorbents is becoming more prominent-green adsorbents. This class of adsorbents offers a dual benefit by removing the contaminants as well as getting rid of the agricultural waste and by-products that would represent a burden on the environment if not properly discarded. Several agricultural waste products (e.g., peels of potatoes, pomegranates, bananas, rice husk, eggshells, crab shells, date pits) have been recycled into adsorbents and were used for the removal of heavy metals, dyes, drugs, etc. [13-18].

Agricultural wastes and products rich in high molecular weight components such as cellulose, hemicelluloses, and lignin would deliver a good quantity of an adsorbent or biomass. Moreover, since these components are rich in functional groups, they are capable of forming different types of bonding (inter- or intramolecular), eventually creating a supramolecular structure capable of adsorbing the contaminants [19]. A literature survey shows that the waste biomasses can be used as they are (untreated or intact) $[20,21]$ following a treatment (activated carbon produced physically or chemically) [22-24] or after conversion into nanoparticles decorated with some functional groups for water remediation $[25,26]$.

Aloe vera (AV) is a succulent plant that belongs to the family Asphodelaceae. The origin of AV is the Arabian Peninsula and regions with tropical/subtropical climates. Yet, it is cultivated all over the world because of its medicinal value, where it has been perceived as a standout amongst the most conspicuous therapeutic plants with diverse applications. AV shell, for example, contains over 75 nutrients, 20 minerals, 18 amino acids, and 12 vitamins. Wound healing, anticancer, antioxidant, immunomodulatory cosmetic, and laxative effects are among the medical applications of AV. Food industry, nanotechnology, and the ecological applications are other applications of AV [27-30].

Developing a green adsorbent from AV waste for the removal of TY from contaminated water samples using an effortless, economical, and efficient method as well as optimization of the adsorption procedure and boosting the removal competency of AV leaves were the tasks undertaken in this methodology. As the purpose is to go "green", an experimental protocol that relies on "Design of Experiments" (DoE) was implemented. Plackett-Burman design (PBD) was the DoE of choice. 
The novelty of this approach, therefore, stems from the conservation of method greenness implementing DoE, which in turn allows for the hoarding of chemicals and resources as well as high-quality data that can be handled with a high degree of confidence. Moreover, the approach followed herein for getting to the ideal adsorbent status (active biomass) did not involve activation using chemicals, and only the raw/burnt masses were used. Table 1 shows a comparison between the AV used for removal of different adsorbates and the AV synthesized in the current approach. Similarly, Table 1 shows a comparison between different adsorbents employed for the removal of TY and the currently used AV leaves [31-35].

Four variables thought to affect the adsorption process-dye concentration (DC), $\mathrm{pH}$ of dye solutions, stirring time (ST), and adsorbent dose (AD) - as well as two responses, percent removal $(\% \mathrm{R})$ and adsorption capacity $\left(q_{e}\right)$, were evaluated and optimized using PBD as a platform. Adsorbent characterization was performed using scanning electron microscopy (SEM) and Brunauer-Emmett-Teller (BET) surface area analysis. Thermogravimetric analysis (TGA), Fourier-transform infrared (FT-IR), Raman spectroscopy, as well as carbon hydrocarbon nitrogen analysis $(\mathrm{CHN})$ were executed. Understanding the adsorption mechanism was achieved following study of the adsorption equilibrium and kinetics. 
Table 1. Comparison between the performance of Aloe Vera (AV) prepared in the current approach and different AV adsorbents as reported in literature as well as the other adsorbents used to remove TY.

\begin{tabular}{|c|c|c|c|c|c|c|c|}
\hline Adsorbent & Modification Method & $\begin{array}{c}\text { Analytical } \\
\text { Approach Used }\end{array}$ & $\begin{array}{l}\text { Surface Area } \\
\quad\left(\mathrm{m}^{2} / \mathrm{g}\right)\end{array}$ & Adsorbate & $\begin{array}{l}\text { Adsorption } \\
\text { Capacity } \\
(\mathrm{mg} / \mathrm{g})\end{array}$ & $\begin{array}{l}\text { Percent } \\
\text { Removal } \\
\text { (\%R) }\end{array}$ & Ref. \\
\hline $\begin{array}{l}\text { *Air dried AV (ADAV) } \\
{ }^{*} \text { Thermally treated AV } \\
\text { (TTAV300) }\end{array}$ & Please see the experimental section of the current approach & $\begin{array}{l}\text { Multivariate } \\
\text { analysis-Plackett-Burman } \\
\text { design (PBD) }\end{array}$ & $\begin{array}{l}3.94 \\
7.076\end{array}$ & TY & 55.25 & $93 \%$ & $\begin{array}{c}\text { Current } \\
\text { work }\end{array}$ \\
\hline $\begin{array}{l}\text { Aloe Vera leaves wastes-based } \\
\text { sulfuric acid modified } \\
\text { activated carbon (AV-SAC) }\end{array}$ & $\begin{array}{l}\text { Leaves' waste was washed with deionized water (DIW) and dried at } 150^{\circ} \mathrm{C} \text { for } 24 \mathrm{~h} \\
\text { and then crushed. Particles were carbonized at } 550^{\circ} \mathrm{C} \text { for } 20 \text { min. The carbonized } \\
\text { sample was treated with sulfuric acid solution for } 12 \mathrm{~h} \text {. The suspension was filtered } \\
\text { and washed with DIW. Finally, the modified activated carbon was dried at } 105^{\circ} \mathrm{C} \text { for } \\
12 \mathrm{~h} \text {. Obtained AV- SAC was crushed and then sieved. }\end{array}$ & $\begin{array}{l}\text { One-factor at a time } \\
\quad \text { (OFAT) }\end{array}$ & ${ }^{*} \mathrm{ND}$ & $\begin{array}{l}\text { Aniline } \\
\text { Methyl } \\
\text { Orange } \\
\text { (MO) }\end{array}$ & 185.18 & ${ }^{*} \mathrm{ND}$ & [31] \\
\hline $\begin{array}{l}\text { Aluminium sulphate-Aloe vera } \\
\text { (ALAV) } \\
\text { Magnesium sulphate-Aloe vera } \\
\text { (MGAV) }\end{array}$ & $\begin{array}{c}\text { Physical blending of } \mathrm{AV} \text { with either } \mathrm{Al} \text { or } \mathrm{Mg}(10 \%: 90 \%) \text { was performed at room } \\
\text { temperature for } 24 \mathrm{~h} .\end{array}$ & $\begin{array}{l}2^{2}-\text { Full factorial } \\
\text { design }\end{array}$ & ${ }^{*} \mathrm{ND}$ & $\begin{array}{l}\text { Methylene } \\
\text { Blue (MB) }\end{array}$ & ${ }^{*} \mathrm{ND}$ & $\begin{array}{l}50-55 \% \\
60-70 \%\end{array}$ & [32] \\
\hline $\begin{array}{l}\text { Aloe vera shell ash (ASA) - } \\
\text { supported } \mathrm{Ni}_{0.5} \mathrm{Zn}_{0.5} \mathrm{Fe}_{2} \mathrm{O}_{4} \\
\text { magnetic nanoparticles }\end{array}$ & $\begin{array}{l}\text { AV shells were washed, dried in an air oven at } 80^{\circ} \mathrm{C} \text { for } 24 \mathrm{~h} \text {, ground, sieved, and } \\
\text { then carbonized at } 700{ }^{\circ} \mathrm{C} \text { for } 2 \mathrm{~h} \text {. Obtained ASA was mixed with the metal nitrates } \\
\text { and dissolved in DIW. Egg-white extract was then mixed with the previous mixture at } \\
\text { room temperature and stirring was applied for } 30 \text { min. Obtained sol-gel was } \\
\text { evaporated at } 80^{\circ} \mathrm{C} \text {. The precursor was ground and calcined in muffle furnace at } 550 \\
{ }^{\circ} \mathrm{C} \text { for } 2 \mathrm{~h} \text {. }\end{array}$ & OFAT & 814.23 & $\mathrm{Ag}(\mathrm{I})$ & 243.9 & $98.30 \%$ & [33] \\
\hline $\begin{array}{l}\text { Aminated calcium } \\
\text { lignosulfonate (ACLS) }\end{array}$ & $\begin{array}{l}\text { Calcium lignosulfonate was modified with triethylene tetramine in the presence of } \\
\text { glutaraldehyde as a crosslinking agent. }\end{array}$ & Orthogonal design & 11.93 & TY & 190.1 & $91 \%$ & [34] \\
\hline $\begin{array}{c}\text { Polyaniline } / \mathrm{Fe}_{3} \mathrm{O}_{4} \\
\left(\mathrm{PANI} / \mathrm{Fe}_{3} \mathrm{O}_{4}\right) \text { nanocomposite } \\
\text { (NC) }\end{array}$ & $\begin{array}{l}\text { Aniline polymerization was conducted in } \mathrm{H}_{2} \mathrm{SO}_{4} \text { medium and in the presence of } \\
\mathrm{Fe}_{3} \mathrm{O}_{4} \text { nanoparticles with ammonium persulfate as an oxidant. Obtained NC were } \\
\text { further washed and dried. }\end{array}$ & OFAT & ${ }^{*} \mathrm{ND}$ & $\mathrm{TY}$ & Dec-34 & ${ }^{*} \mathrm{ND}$ & [35] \\
\hline
\end{tabular}




\section{Experimental}

\subsection{Materials and Reagents}

All reagents and chemicals were of analytical grade and were used without further purification. Sodium hydroxide, sodium tetraborate-10-hydrate $\left(\mathrm{Na}_{2} \mathrm{~B}_{4} \mathrm{O}_{7} \cdot 10 \mathrm{H}_{2} \mathrm{O}\right)$, and hydrochloric acid were purchased from Sigma-Aldrich (Darmstadt, Germany). Ultrapure water (18.2 $\mathrm{M} \Omega$ ) was used to prepare and dilute dye solutions. Titan yellow (TY) was purchased from Riedel-dehaën (Seelze, NI, Germany). The $\mathrm{pH}$ of dye solutions was adjusted using a buffer prepared using a mixture of $\left(\mathrm{Na}_{2} \mathrm{~B}_{4} \mathrm{O}_{7} \cdot 10 \mathrm{H}_{2} \mathrm{O}\right.$, $50 \mathrm{mM}$ ) and $0.1 \mathrm{M} \mathrm{NaOH}$ or $0.1 \mathrm{M} \mathrm{HCl}$. Further adjustments of $\mathrm{pH}$ were done using small increments of $0.1 \mathrm{M} \mathrm{NaOH}$ and $0.1 \mathrm{M} \mathrm{HCl}$. The color of the dye did not change over the investigated $\mathrm{pH}$ range.

\subsection{Instrumentation and Software}

A UV-Vis spectrophotometer (Agilent diode-array, CA, USA) with $10 \mathrm{~mm}$ matched quartz cells was used to measure the absorbance of the samples. A centrifuge (Thermo Scientific, ST8 Benchtop, Waltham, MA, USA) was used for the separation of the supernatant. The $\mathrm{pH}$ of the prepared solutions was adjusted using a Jenway $\mathrm{pH}$ meter (Jenway, Staffordshire, UK).

The fully dried air-dried Aloe vera (ADAV) and the thermally treated Aloe vera (TTAV300) samples were sprayed with gold, and the surface morphology of the samples was investigated using scanning electron microscope (SEM, FEI, Quanta 200, Thermo Scientific ${ }^{\mathrm{TM}}$, Waltham, MA, USA) under an accelerating voltage of $30 \mathrm{kV}$ and by using a standard secondary electron (SE) detector, while the distribution of elements on the surface was determined by energy dispersive X-ray (EDS) detector.

Fourier transform infrared radiation (FT-IR, Bruker Alpha, MA, USA) was used to recognize the functional groups on the surface of the prepared adsorbent. Spectra were collected in the range of $400-4000 \mathrm{~cm}^{-1}$ with a resolution factor of $4 \mathrm{~cm}^{-1}$. The Raman spectrum of the ADAV and the TTAV300 were acquired in the range from $50-3500 \mathrm{~cm}^{-1}$ using a DXRTM2 Raman microscope (Thermo Scientific ${ }^{\mathrm{TM}}$, Waltham, MA, USA) with a laser beam at $532 \mathrm{~nm}$ as the excitation source and $10 \mathrm{~mW}$ power. A thermal gravimetric analyzer (TGA, PerkinElmer-TGA400, Waltham, MA, USA) was employed to investigate the thermal stability of the prepared AV at a temperature range of $50-800{ }^{\circ} \mathrm{C}$.

Analysis of the adsorbent's surface area was performed using a Micromeritics ASAP2020 Accelerated Surface Area and Porosimetry System (Micrometrics, Norcross, GA, USA). Degassing of samples was initially employed followed by investigating $\mathrm{N}_{2}$ adsorption-desorption. Using the $\mathrm{N}_{2}$ isotherms collected at $77 \mathrm{~K}$ and employing the Brunauer-Emmett-Teller (BET) equation, surface area was determined. Pore volume was established using the $\mathrm{t}$-plots and the Barrett-Joyner-Halenda (BJH) equation.

Minitab ${ }^{\circledR} 18$ software was purchased from Minitab Inc., State College, Pennsylvania, USA. The software was used to make the list of experiments according to the selected design.

\subsection{Preparation of Adsorbate}

Water samples artificially contaminated with TY were prepared by dissolving the prerequisite amounts of TY in ultrapure water to a final concertation of $100 \mathrm{ppm}$ stock solution. Serial dilutions of the dye solution were prepared in the same solvent, and the $\mathrm{pH}$ was adjusted to the desired value using borate buffer. Three calibration curves of TY at the tested pH levels (Table 2, low, central, and high) were constructed by measuring different concentrations of TY at $406 \mathrm{~nm}$. 
Table 2. PBD design matrix for the coded independent variables. Response is shown as observed and predicted $\%$ R of TY as well as the adsorption capacity $\left(q_{e}\right)$ using ADAV biomass.

\begin{tabular}{|c|c|c|c|c|c|c|c|c|}
\hline \multirow{2}{*}{\multicolumn{5}{|c|}{ Independent Variables and Their Codes }} & \multicolumn{4}{|c|}{ Ranges and Levels } \\
\hline & & & & & \multicolumn{2}{|c|}{-1, Low } & 0, Central & +1 , High \\
\hline \multicolumn{5}{|c|}{$\mathrm{pH}(\mathrm{pH}, \mathbf{A}, \mathrm{pH}$ unit $)$} & \multicolumn{2}{|c|}{4.00} & 8.00 & 12.00 \\
\hline \multicolumn{5}{|c|}{ Adsorbent dose (AD, B, mg/50 mL) } & \multicolumn{2}{|c|}{100} & 300 & 500 \\
\hline \multicolumn{5}{|c|}{ Dye concentration (DC, C, ppm) } & \multicolumn{2}{|c|}{10} & 55 & 100 \\
\hline \multicolumn{5}{|c|}{ Stirring time (ST, D, min.) } & \multicolumn{2}{|c|}{5} & 32.5 & 60 \\
\hline \multirow[t]{2}{*}{ Run } & \multicolumn{4}{|c|}{ Coded levels of variables } & \multicolumn{2}{|c|}{ Response (Y1, \%R) } & \multicolumn{2}{|c|}{$\begin{array}{c}\text { Response (Y2, adsorption } \\
\left.\text { capacity, } q_{e}\right)\end{array}$} \\
\hline & $A^{a}$ & $\mathbf{B}^{\mathbf{b}}$ & $\mathrm{C}^{\mathrm{c}}$ & $D^{d}$ & * Obs. & ** Pred. & * Obs. & ** Pred. \\
\hline 01 & -1 & +1 & +1 & -1 & 85.00 & 83.94 & 7.68 & 10.5 \\
\hline 02 & 0 & 0 & 0 & 0 & 79.34 & 79.61 & 7.20 & 7.25 \\
\hline 03 & +1 & +1 & +1 & -1 & 52.50 & 42.09 & 5.24 & 3.54 \\
\hline 04 & +1 & +1 & -1 & +1 & 13.24 & 13.97 & 0.13 & 0.13 \\
\hline 05 & +1 & +1 & -1 & +1 & 11.00 & 13.97 & 0.07 & 0.13 \\
\hline 06 & 0 & 0 & 0 & 0 & 79.88 & 79.61 & 7.30 & 7.25 \\
\hline 07 & -1 & -1 & -1 & -1 & 30.05 & 34.93 & 1.47 & 2.10 \\
\hline 08 & -1 & -1 & +1 & +1 & 41.74 & 48.85 & 20.9 & 27.9 \\
\hline 09 & -1 & +1 & +1 & +1 & 93.00 & 95.63 & 9.27 & 7.27 \\
\hline 10 & +1 & -1 & +1 & -1 & 26.90 & 25.73 & 10.9 & 13.6 \\
\hline 11 & -1 & -1 & -1 & +1 & 30.13 & 23.80 & 2.25 & 1.45 \\
\hline 12 & -1 & +1 & -1 & -1 & 72.84 & 79.88 & 0.73 & 0.55 \\
\hline 13 & +1 & -1 & +1 & +1 & 18.66 & 17.53 & 11.4 & 9.35 \\
\hline 14 & +1 & -1 & -1 & -1 & 12.10 & 12.53 & 0.88 & 0.71 \\
\hline
\end{tabular}

* Obs.: experimental values, ${ }^{* *}$ Pred.: predicted values following the process of response transformation.

\subsection{Adsorbent Preparation}

\subsubsection{Air Dried Aloe Vera (ADAV)}

Fresh, green AV leaves were collected from a yard/home garden in Doha-Qatar. The collected leaves were washed copiously with deionized water (DIW) several times to remove dust and impurities. The gel of AV leaves was carefully removed using a razorblade. Leaves were washed again with DIW several times. Clean, empty leaves were then cut into small pieces of approximately $1 \times 1 \mathrm{~cm}$ and left to dry in shade and in the presence of the air conditioner for 5 successive days. AV leaves were thereafter dried in an oven at $50-52{ }^{\circ} \mathrm{C}$ for $2 \mathrm{~h}$. It is noteworthy to mention that the oven temperature was kept at less than $60{ }^{\circ} \mathrm{C}$ so as to eliminate water and to conserve the organic components simultaneously. The dried AV shells were then ground into very fine powder using a non-metallic electric grinder, sieved using a $1 \mathrm{~mm}$ mesh size, and divided into two portions. One portion was kept in the desiccator and was used for the adsorption experiments without any further treatment and was labeled as ADAV. The second portion underwent thermal treatment as in the subsequent section.

\subsubsection{Thermally Treated Aloe Vera (TTAV)}

ADAV prepared under the aforementioned mild conditions was thermally treated at different temperatures ranging from $300-500{ }^{\circ} \mathrm{C}$ for $1 \mathrm{~h}$ and labeled as TTAV300, TTAV400, and TTAV500.

\subsection{Evaluation of Adsorption Capability of the Prepared Adsorbent(s)}

Performance of the prepared adsorbents was assessed by comparing the $\% \mathrm{R}$ and the $q_{e}$ for the four adsorbents (ADAV, TTAV300, TTAV400, and TTAV500). The two quantities were measured using Equations (1) and (2). Assessments showed that ADAV and TTAV300 had the best performance with ADAV being superior, as shown in Table 3. The impact of the four variables on the performance of ADAV as an adsorbent was tested following the experimental setup shown in Table 2. Two sets of 
$15 \mathrm{~mL}$ centrifuge tubes were prepared. An amount of 30-150 mg of ADAV was added to each tube. The $\mathrm{pH}$ of TY solutions (10-100 ppm) was adjusted using borate buffer to the desired $\mathrm{pH}$ value (Table 2). Blanks were similarly prepared but without TY in the second set. The two sets were then centrifuged at $4200 \mathrm{rpm}$ for the stirring time (ST) specified in Table 2. The absorbance of the supernatant was measured using UV-Vis spectrophotometer.

$$
\begin{gathered}
(\% \mathrm{R}, \mathrm{Y} 1)=\frac{C_{0}-C_{e}}{C_{0}} \times 100 \% \\
(q e, \mathrm{Y} 2)=\frac{C_{0}-C_{e}}{W} V
\end{gathered}
$$

where $C_{\mathrm{e}}\left(\mathrm{mg} \mathrm{L}^{-1}\right)$ is the concentration of TY aqueous solution at equilibrium, $C_{0}\left(\mathrm{mg} \mathrm{L}^{-1}\right)$ is the initial concentration of TY in aqueous solution, $V$ is the volume of the solution in liters (L), and $W$ is the weight of the ADAV in $(\mathrm{g})$.

Table 3. A comparison between the adsorption capabilities of the four adsorbents in terms of $\% \mathrm{R}$ and $q_{e}$ $(\mathrm{AD}=200 \mathrm{mg} / 50 \mathrm{~mL}, \mathrm{pH}=9, \mathrm{ST}=30 \mathrm{~min}$, and $\mathrm{DC}=100 \mathrm{ppm})$. The responses shown were calculated using Equations (1) and (2).

\begin{tabular}{ccc}
\hline Tested Adsorbent & \% Removal $(\% \mathbf{~ R})$ & Adsorption Capacity $\left(\boldsymbol{q}_{e}, \mathbf{m g} / \mathbf{g}\right)$ \\
\hline ADAV & 79.44 & 11.92 \\
TTAV300 & 70.85 & 10.63 \\
TTAV400 & 37.07 & 5.561 \\
TTAV500 & 31.08 & 4.662 \\
\hline
\end{tabular}

\subsection{Experimental Design}

PBD was the design of choice in the current approach. Four independent variables were investigated at two levels (Table 2). Two responses were measured as a function of the four variables. In this itinerary, 14 base runs were generated in two blocks and with two added central points. The design matrix in terms of uncoded variables is shown in Table $2[14,36,37]$.

\subsection{Equilibrium and Kinetics Studies}

For equilibrium studies, a stock solution of 1000 ppm TY was prepared. Further dilutions of the stock solution (5-400 ppm) were prepared in the same solvent, and the $\mathrm{pH}$ was adjusted to $\mathrm{pH}$ $4.00 \pm 0.20$ using borate buffer solution. Equal quantities of $\mathrm{ADAV}(0.1 \mathrm{~g} \pm 0.005)$ were added to $13 \mathrm{~mL}$ of the previously prepared solutions, and then the solution was shaken using the automatic shaker at $150 \mathrm{rpm}$ for $2 \mathrm{~h}$ and then filtered. Absorbance of the filtrate was measured at $406 \mathrm{~nm}$. The kinetics studies were conducted using $200 \mathrm{~mL}$ TY dye solution (200 ppm, pH $4.00 \pm 0.20$ ) and $\sim 1.5 \mathrm{~g}$ of ADAV with shaking. One sample was taken at time range around 1 min over a time span of $15 \mathrm{~min}$.

\section{Results and Discussion}

\subsection{Plackett-Burman Design (PBD)}

As previously mentioned, the purpose of the current investigation was not only to recycle the agro-waste into a convenient adsorbent but also to augment the adsorption efficiency of the selected bio-sorbent without using extensive chemical or physical treatment. This objective could be attained via the application of PBD as a platform. The experimental setup was established following the scenario exhibited in Table 2. As a screening approach, PBD is commonly used to investigate the main effects, where they are usually deeply confounded with the factorial interactions $[14,36,37]$. Two responses were considered for the current investigation: $\% \mathrm{R}$ and $q_{e}$. The target was to maximize each response. 


\subsubsection{Investigation of Statistically Significant Variables}

A Pareto chart of the standardized effects was used to decide upon the statistically significant variables. As shown in Figure 2, the left panel shows that $\mathrm{pH}$ (A) was the most statistically significant variable affecting the \%R compared to dye concentration (DC) (C) in the case of $q_{e}$ (right panel). Analysis of variance (ANOVA) data are shown in Table 4. The data shown further confirm the findings of the Pareto chart with normal and half-normal probability plots (not shown). Statistical significance of the tested variables at 95.0 confidence intervals $(95.0 \mathrm{CI})$ was estimated by F-test and $p$-value $<0.05$. It is noteworthy to mention that a significant improvement in data quality was observed following response transformation by employing Box-Cox transformation [Equation (3)] together with stepwise analysis in the case of $\% \mathrm{R}$ and forward selection in the case of $q_{e}[38-40]$.

$$
\mathrm{Y}^{\prime}=\left(\mathrm{Y}_{\lambda}-1\right) / \lambda
$$

where $Y^{\prime}$ is the transformed response and $\lambda$ is the transformation factor.
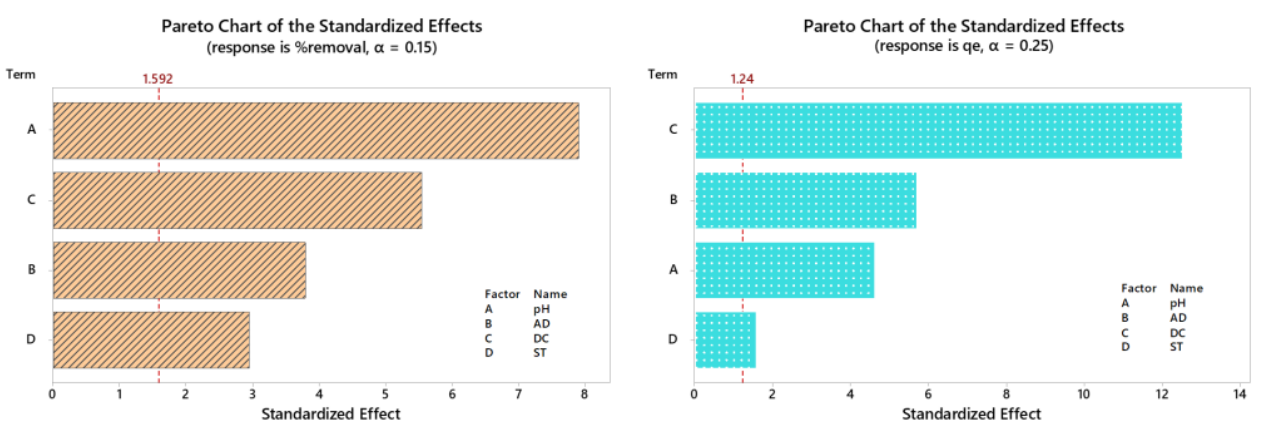

Figure 2. Pareto chart of standardized effects obtained following response optimization.

Table 4. Results of ANOVA for the transformed responses.

\begin{tabular}{|c|c|c|c|c|c|c|c|c|c|}
\hline \multirow{2}{*}{$\frac{\text { Response }}{\text { Source }}$} & \multirow{2}{*}{$\mathrm{DF}^{*}$} & \multicolumn{4}{|c|}{$\% R$} & \multicolumn{4}{|c|}{$q_{e}$} \\
\hline & & Adj SS * & Adj MS * & $f$-Value & $p$-Value & Adj SS * & Adj MS * & $F$-Value & $p$-Value \\
\hline Model & 5 & 7.33116 & 1.46623 & 28.99 & 0.000 & 37.9965 & 7.5993 & 45.25 & 0.000 \\
\hline Linear & 4 & 5.87250 & 1.46813 & 29.03 & 0.000 & 35.6767 & 8.9192 & 53.11 & 0.000 \\
\hline $\mathrm{pH}$ & 1 & 3.15187 & 3.15187 & 62.32 & 0.000 & 3.5806 & 3.5806 & 21.32 & 0.002 \\
\hline $\mathrm{AD}$ & 1 & 0.72725 & 0.72725 & 14.38 & 0.005 & 5.4182 & 5.4182 & 32.26 & 0.000 \\
\hline DC & 1 & 1.55138 & 1.55138 & 30.67 & 0.001 & 26.2590 & 26.2590 & 156.35 & 0.000 \\
\hline ST & 1 & 0.44201 & 0.44201 & 8.74 & 0.018 & 0.4190 & 0.4190 & 2.50 & 0.153 \\
\hline Curvature & 1 & 1.45866 & 1.45866 & 28.84 & 0.001 & 2.3198 & 2.3198 & 13.81 & 0.006 \\
\hline Error & 8 & 0.40463 & 0.05058 & & & 1.3436 & 0.1679 & & \\
\hline Lack-of-Fit & 6 & 0.38743 & 0.06457 & 7.51 & 0.122 & 1.1124 & 0.1854 & 1.60 & 0.432 \\
\hline $\begin{array}{l}\text { Pure } \\
\text { Error }\end{array}$ & 2 & 0.01720 & 0.00860 & & & 0.2312 & 0.1156 & & \\
\hline Total & 13 & 7.73579 & & & & 39.3401 & & & \\
\hline
\end{tabular}

Equations (4) and (5) are the regression models that describe the relation between the measured responses and the investigated variables and accordingly can be used to predict the \%R and the $q_{e}$. These models were obtained following response transformation.

$$
\begin{aligned}
& \ln (\mathrm{Y} 1, \% \mathrm{R})=3.898-0.1281 \mathrm{pH}+0.001231 \mathrm{AD}+0.00799 \mathrm{DC}-0.00698 \mathrm{ST}+0.922 \mathrm{Ct} . \text { Pt. } \\
& \ln \left(\mathrm{Y} 2, q_{\mathrm{e}}\right)=1.331-0.1366 \mathrm{pH}-0.003360 \mathrm{AD}+0.03287 \mathrm{DC}-0.00680 \mathrm{ST}+1.163 \mathrm{Ct} . \text { Pt. }
\end{aligned}
$$


To test the applicability of the proposed models, the experimental values of the two responses- $\% \mathrm{R}$ and $q_{\mathrm{e}}$-were compared to the model predicted values (Table 2). Results show a good agreement between both. The values of the coefficient of determination $\left(R^{2}\right)$ were high enough $(0.9477$ and 0.9658 for $\% \mathrm{R}$ and $q_{\mathrm{e}}$, respectively) to indicate the model linearity. The potential of the suggested models to foresee new responses was spotted from the high values of $R^{2}$ (predicted) observed following response transformation ( 0.8463 and 0.8996 for $\% \mathrm{R}$ and $q_{\mathrm{e}}$, respectively). As shown from the two regression equations, while the adsorbent dose (AD) was positively impacting the $\% R$, it negatively impacted the $q_{\mathrm{e}}$. The direction of the rest of the effects was the same for both responses.

\subsubsection{Contour and Surface Plots}

The $2 \mathrm{D}$ and the 3D plots for the response surface versus the significant factorial interactions are shown in Figure 3. The left panel is a sample 2D plot that shows the factorial interactions, where $\mathrm{pH}$ and DC are represented on the $\mathrm{X}$ - and the $\mathrm{Y}$-axes, while the $\% \mathrm{R}$ is denoted by the contour lines. As shown on the graph and as per the associated legend, the darkest green zone signifies a zone with the maximum response (greater than $90 \%$ removal of TY). The right panel of Figure 3 displays a similar liaison; however, it is shown in the $3 \mathrm{D}$ arrangement where the measured $\% \mathrm{R}$ is represented on the Z-axis. As shown, the maximum \%R (exceeding $75 \%$ ) would be attained by employing a DC between 50-70 ppm and a $\mathrm{pH}$ value of $4-7$.
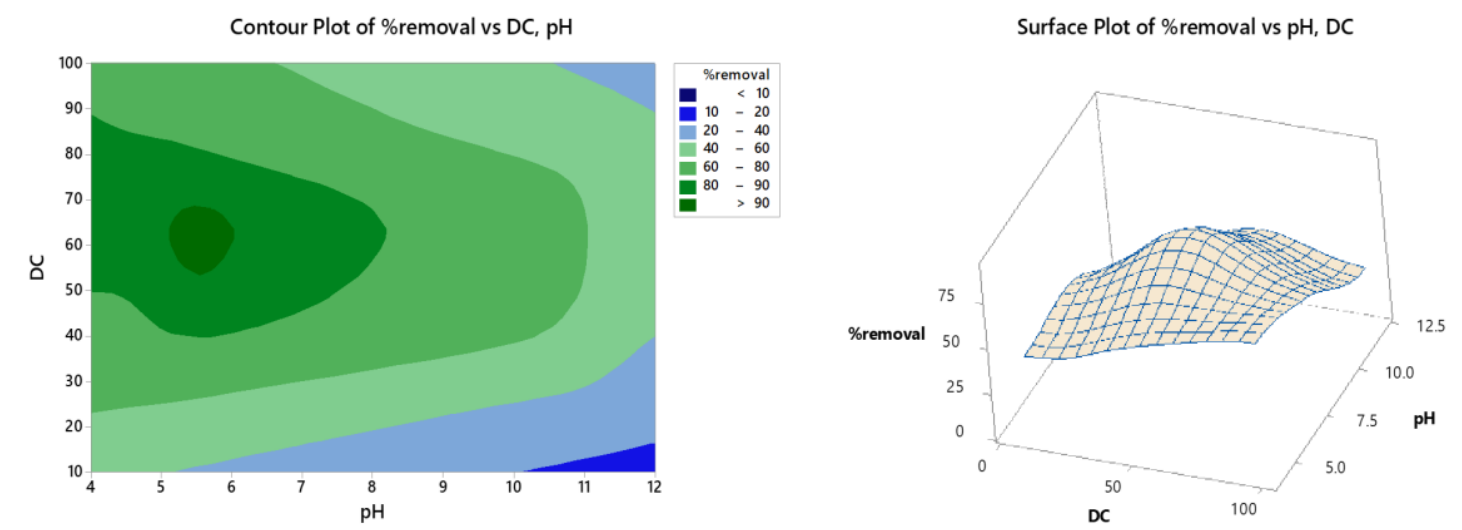

Figure 3. Sample contour (2D) and surface (3D) plots for the relationship between DC, pH, and \%R.

Optimum conditions for maximizing each response (individually) were obtained using the Minitab response optimizer. Data obtained show that maximum $\% \mathrm{R}$ was achieved with a desirability of $d=1.0000$ and using a factorial combination of $\mathrm{pH}=4, \mathrm{AD}=500 \mathrm{mg} / 50 \mathrm{~mL}, \mathrm{DC}=100 \mathrm{ppm}$, and $\mathrm{ST}=5 \mathrm{~min}$. This high value of desirability function (d) indicates that the proposed factorial combination was in favor of maximum \%R. The increase in \%R with the increase of AD and DC implies that adsorption sites were not getting saturated, even with higher dye concentrations. Maximum $q_{e}$, however, was obtained using a combination of $\mathrm{pH}=4, \mathrm{AD}=100 \mathrm{mg} / 50 \mathrm{~mL}, \mathrm{DC}=100 \mathrm{ppm}$, and $\mathrm{ST}=5 \mathrm{~min}$ with a desirability of $\mathrm{d}=1.0000$. This can be explained since $q_{e}$ could be maximized using the lowest $\mathrm{AD}$ and the highest $\mathrm{DC}$, as shown in Equation (2).

\subsection{Adsorbent Characterization}

\subsubsection{TGA Analysis of ADAV}

Thermogravimetric analysis of ADAV was performed under $\mathrm{N}_{2}$ and with a heating rate of $10^{\circ} \mathrm{C} / \mathrm{min}$. As shown in Figure 4, the weight loss in the samples occurred over three steps:

1. Loss of adsorbed water and solvent molecules at $25-150{ }^{\circ} \mathrm{C}$, while the crystalline water was lost at $200{ }^{\circ} \mathrm{C}$, which represented $6.5 \%$ of the sample; 
2. In this step, more than $51 \%$ of the sample was decomposed between $\left(200-600^{\circ} \mathrm{C}\right)$, and there were four peaks - two major peaks at $273.2^{\circ} \mathrm{C}$ and $316.3^{\circ} \mathrm{C}$, and two other small peaks at $370.6{ }^{\circ} \mathrm{C}$ and $436.8^{\circ} \mathrm{C}$. Therefore, at least four decomposition mechanisms could be involved [41];

3. The third step $\left(600-800{ }^{\circ} \mathrm{C}\right)$ represented nearly $9.9 \%$ of the sample and could be attributed to the carbonization of polymeric material [42].

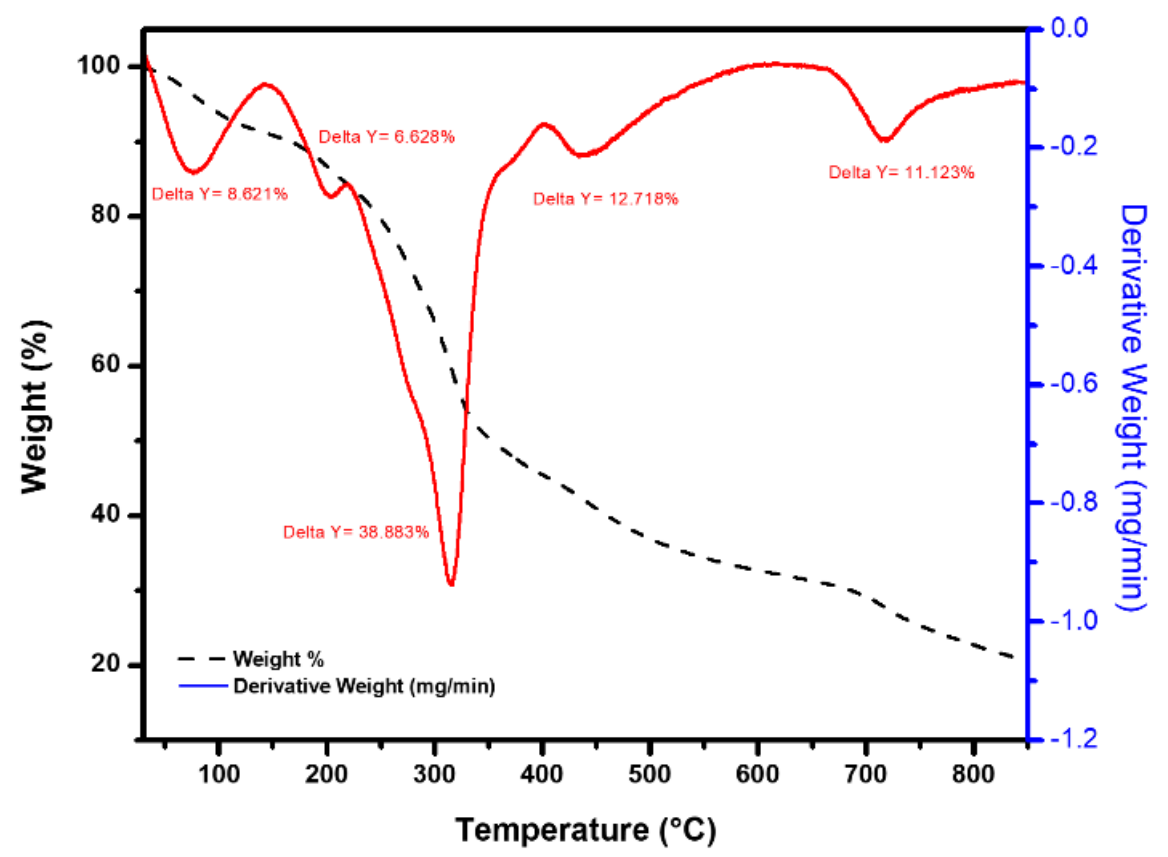

Figure 4. TGA/dTGA analysis of ADAV sample.

\subsubsection{FT-IR Analysis of ADAV and TTAV300}

The FT-IR spectra of ADAV and TTAV300 are shown in Figure 5. The revealed spectrum of ADAV exhibited a broad band positioned at $3300 \mathrm{~cm}^{-1}$, which was attributed to the stretching vibration of the $-\mathrm{OH}$ groups that characterized the carbohydrate monomers together with mannose and uronic acid. Moreover, the spectrum showed two absorption bands at 2916 and $2850 \mathrm{~cm}^{-1}$, which could be assigned to the symmetrical and the asymmetrical $\mathrm{C}-\mathrm{H}$ stretching. The absorption band at $1731 \mathrm{~cm}^{-1}$ was characteristic for $\mathrm{C}=\mathrm{O}$ stretching and confirmed the presence of a carbonyl moiety. The absorption peak at $1586 \mathrm{~cm}^{-1}$ may have been associated with the asymmetrical and the symmetrical $-\mathrm{COO}^{-}$stretching of carboxylate compounds. Furthermore, the two absorption peaks at 1250 and $1153 \mathrm{~cm}^{-1}$ corresponded to the presence of $\mathrm{C}-\mathrm{C}$ stretching and $\mathrm{C}-\mathrm{O}-\mathrm{C}$ stretching of aliphatic ether, respectively. The absorption peak at $1019 \mathrm{~cm}^{-1}$ may have been due to $\mathrm{C}-\mathrm{O}$ stretching associated with rhamnogalacturonan, a side-chain component of pectins $[43,44]$. 


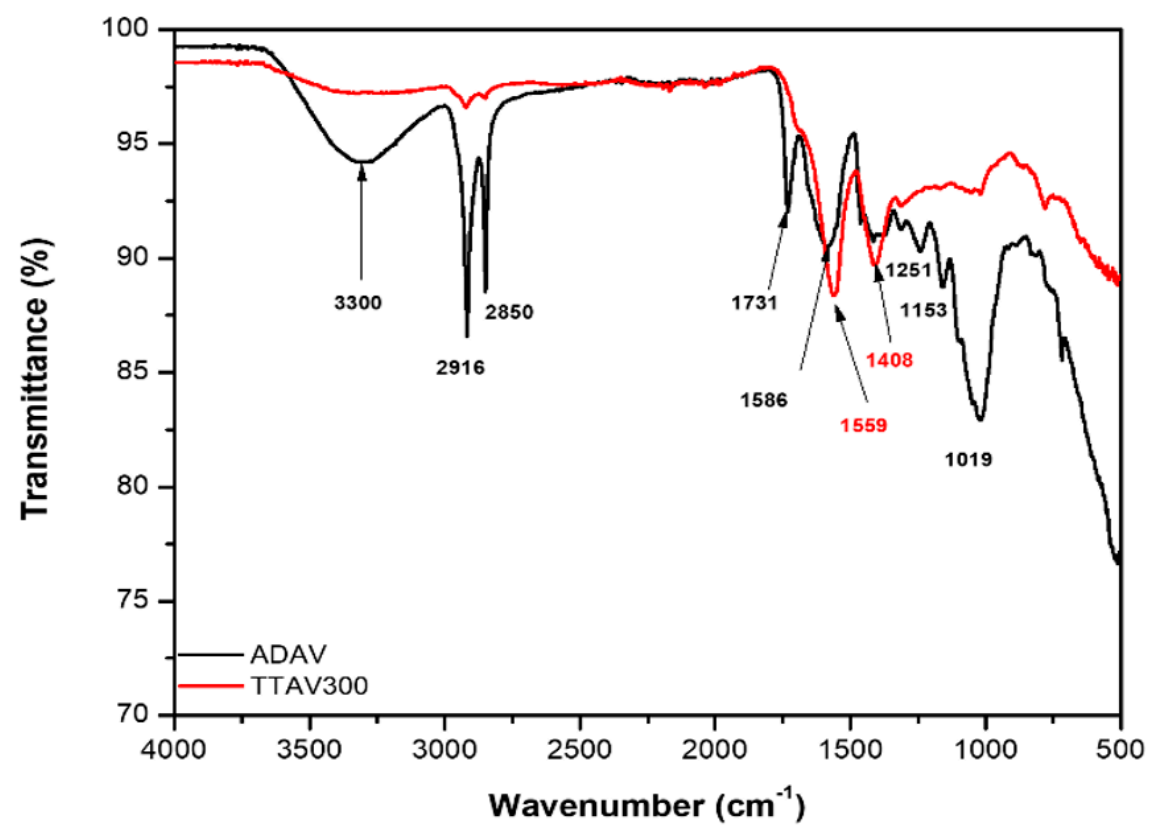

Figure 5. FT-IR spectra of ADAV and TTAV300.

On the other hand, the spectrum of TTAV300 showed the presence of some peaks similar to those of $\mathrm{ADAV}$, however, with a lower absorption intensity due to the thermal treatment. Moreover, two strong absorption peaks appeared at 1559 and $1409 \mathrm{~cm}^{-1}$, which could be attributed to the presence of -COOstretching of carboxylate compounds in the thermally treated sample.

\subsubsection{CHN Analysis}

Data presented in Table 5 confirmed the findings of the FT-IR analysis. As shown, the percentage of hydrogen decreased from $5.34 \%$ to $4.22 \%$ following the thermal treatment. This could have been caused by the loss of water during the heating of samples. On the other hand, the percentage of nitrogen was almost the same in both adsorbents. The percentage of carbon, as expected, increased from $35 \%$ to $53 \%$ in the thermally treated sample, and this also confirmed the presence of carbon-oxygen and carbon-nitrogen functional groups in both adsorbents.

Table 5. Carbon hydrocarbon nitrogen $(\mathrm{CHN})$ analysis of the prepared adsorbents.

\begin{tabular}{cccc}
\hline Adsorbent & $\mathbf{N ~ ( \% )}$ & $\mathbf{C ~ ( \% )}$ & H (\%) \\
\hline ADAV & 0.96 & 35.79 & 5.34 \\
TTAV300 & 1.10 & 52.73 & 4.22 \\
\hline
\end{tabular}

\subsubsection{Raman Analysis of ADAV and TTAV300}

Raman spectra of ADAV and TTAV300 are shown in Figure 6. The spectrum of ADAV did not show any peaks, probably because carbon exists as an organic matter. On the other hand, the spectrum of TTAV300 had a clear D- band, which appeared at $1351 \mathrm{~cm}^{-1}$, and a clear G- band at $1585 \mathrm{~cm}^{-1}$. These two peaks were distinctive in the spectra of all carbonaceous materials, and their arrangement was the same as graphene oxide [45]. 


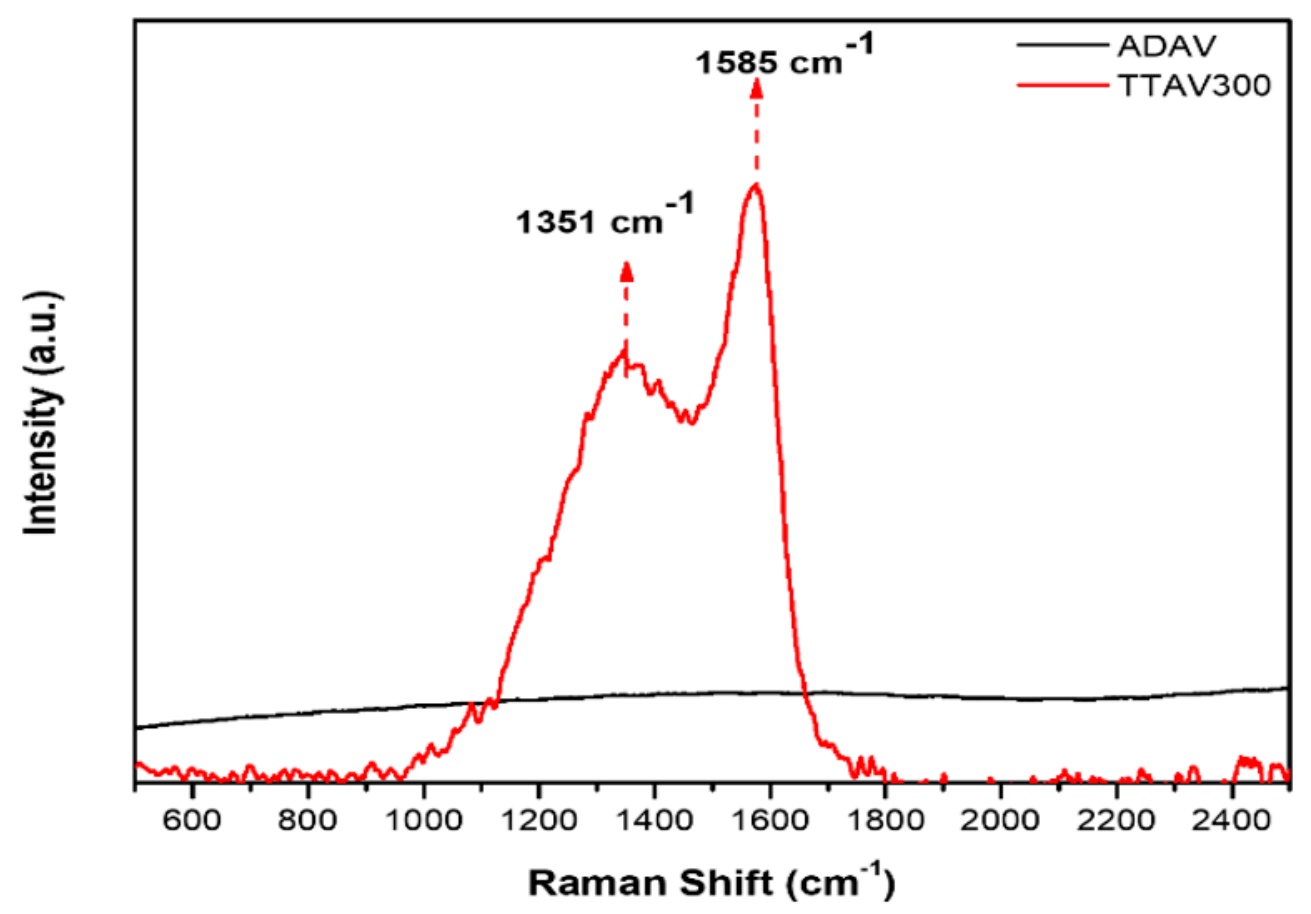

Figure 6. Raman spectra of ADAV and TTAV300.

The properties of the carbon lattice, including defects and sizes, were displayed by the D- band; however, it did not display the chemical conformation of the carbon materials. The wavelength of the laser beam mainly affected the position of the D- band. On the other hand, the G- band identified the stretching of C-C for the $s p^{2}$ system [46]. Obtained data confirmed the formation of activated carbon in the case of TTAV300, and this was confirmed by the presence of the two bands (G- and D-).

\subsubsection{BET Analysis}

The surface areas (SAs) of ADAV and TTAV300 were measured, as shown in Figure 7. The obtained data showed that Langmuir SAs were 3.940 and $7.076 \mathrm{~m}^{2} / \mathrm{g}$ for ADAV and TTAV300, respectively. Besides, the single point total pore volumes were 0.011197 and $0.020461 \mathrm{~cm}^{3} / \mathrm{g}$ for ADAV and TTAV300 samples, respectively. Moreover, the single point average pore radii were found to be $98.6^{\circ} \mathrm{A}$ for ADAV and $68.4^{\circ} \mathrm{A}$ in the case of TTAV300. The obtained data indicated that the thermal treatment process of the AV samples did not have a significant impact on the surface area and the pore size of the prepared samples and, as a result, the adsorption efficiency of TTAV samples was not affected by thermal treatment $[45,46]$. On the other hand, using the International Union of Pure and Applied Chemistry (IUPAC) definition for mesoporous and macroporous materials, the pore diameter patterns of both ADAV and TTAV300 showed two types of pores: mesoporous (less than $50 \mathrm{~nm}$ in diameter) and macrospores (greater than $50 \mathrm{~nm}$ in diameter). These types of pore systems serve to increase the surface area of the adsorbent and hence its adsorption capacity [16]. 

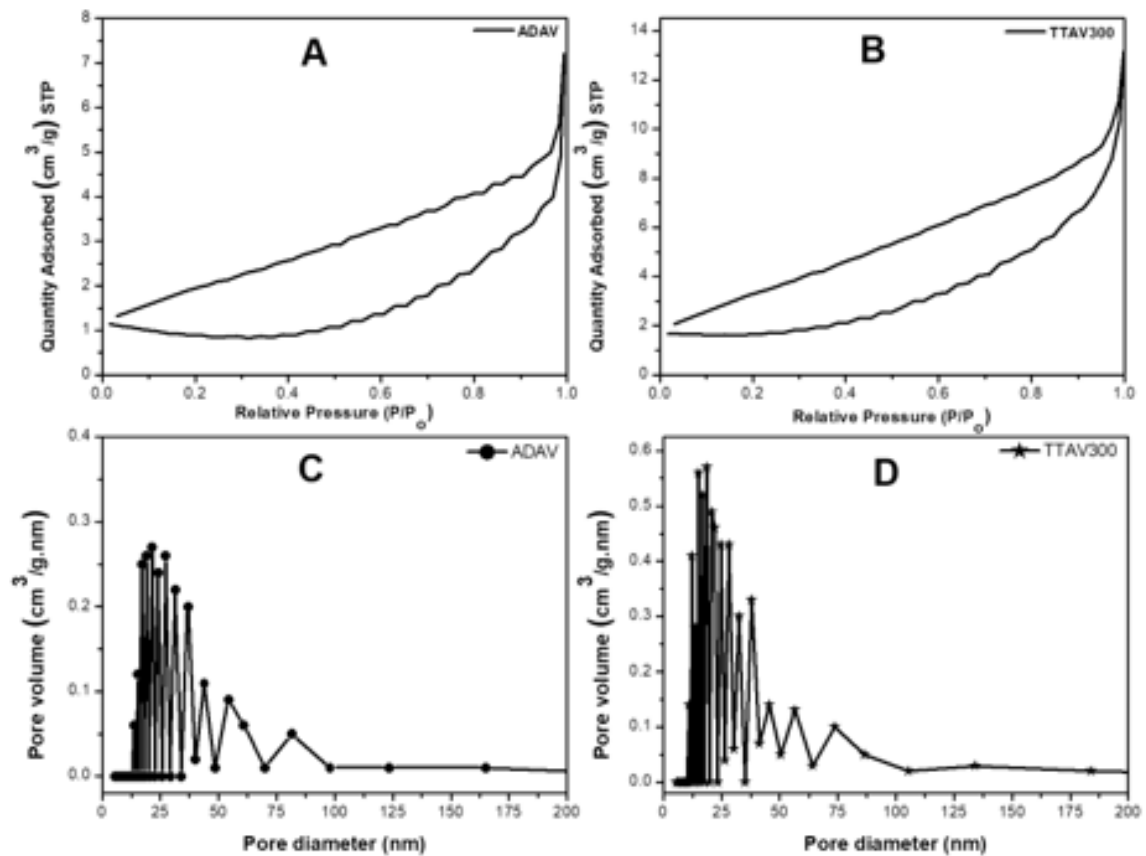

Figure 7. Nitrogen adsorption-desorption isotherms at $77 \mathrm{~K}$ for ADAV (A) and TTAV300 (B) and the relation between pore volume and diameter for both ADAV (C) and TTAV300 (D).

\subsubsection{SEM and EDX Analyses}

Surface morphologies of ADAV and TTAV300 were investigated using SEM. Micrographs shown in Figure 8A,B indicate that ADAV and TTAV300 contained a number of pores with different radii. These data confirmed the loss of some volatile and organic matter at $300{ }^{\circ} \mathrm{C}$ and the formation of carbonaceous mass with an advanced pore structure. These findings are in alignment with the BET surface area and the TGA analyses of other thermally treated adsorbents [14-16]. On the other hand, energy dispersive X-ray spectroscopy (EDX) analysis was used to study the elemental compositions of ADAV and TTAV300. Obtained results show that the TTAV300 was mainly composed of carbon $(92.75 \%)$ in comparison to $72.55 \%$ for ADAV (Figure $8 \mathrm{C}, \mathrm{D}$ ). Other elements such as $\mathrm{Na}, \mathrm{Mg}, \mathrm{P}, \mathrm{Cl}, \mathrm{Ca}$, and $\mathrm{Ca}$ were also present, and their total concentration was less than $2 \%$. These results confirm the formation of carbonaceous material following the thermal treatment.
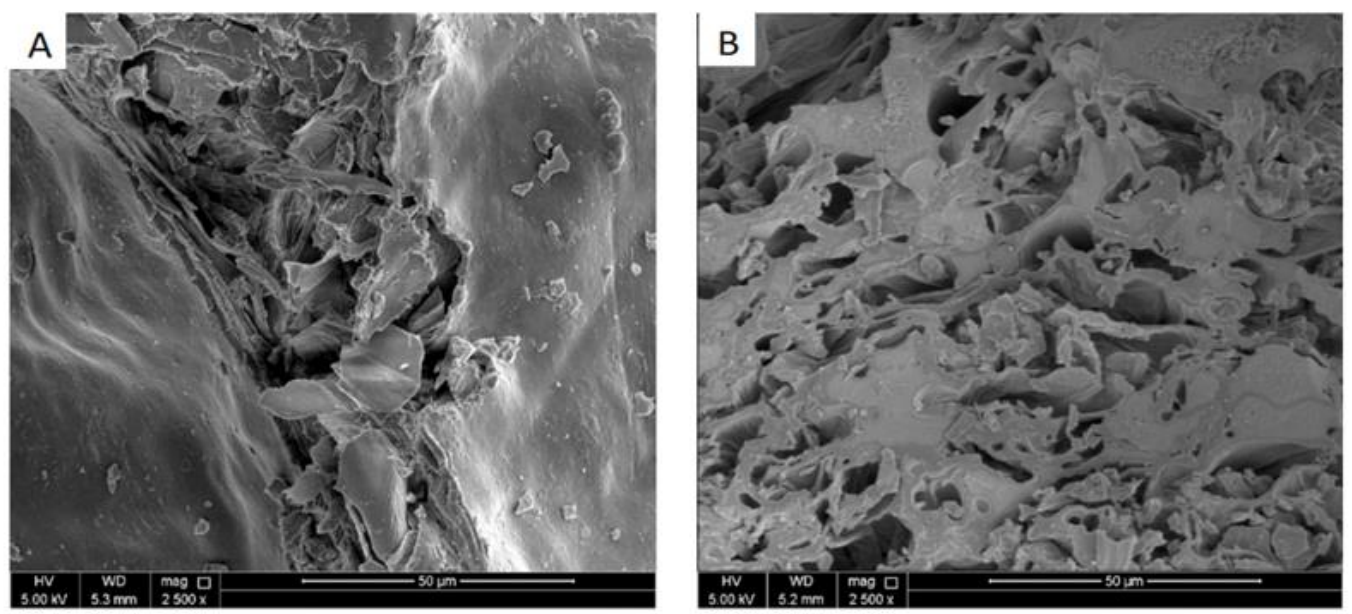

Figure 8. Cont. 

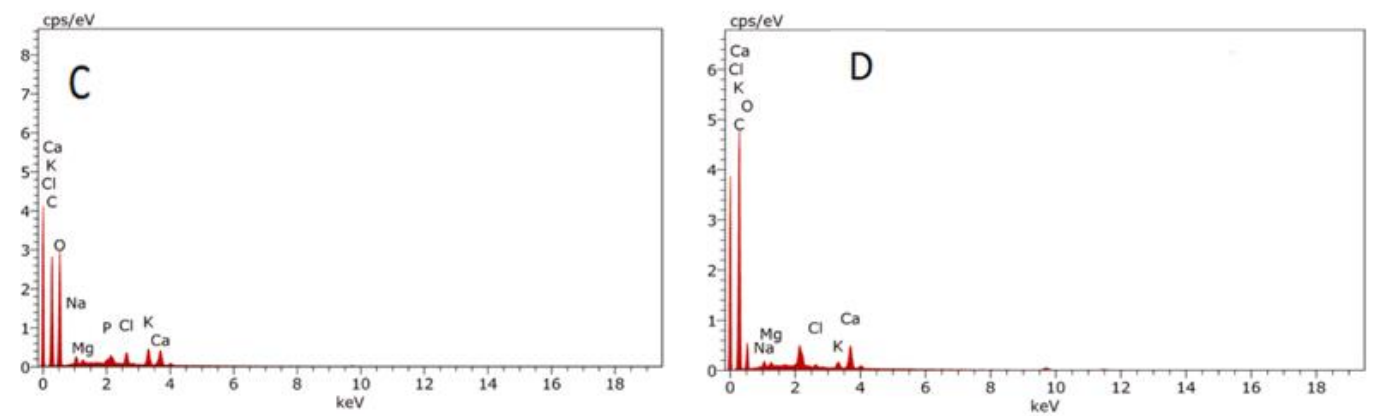

Figure 8. SEM micrographs of ADAV (A), TTAV300 (B), as well as energy dispersive X-ray spectroscopy (EDX) analysis of ADAV (C) and TTAV300 (D).

\subsection{Equilibrium and Kinetics Studies}

Preliminary studies have shown that the ADAV is more powerful compared to the TTAV samples in biosorption removal of TY. Therefore, the equilibrium and the kinetics studies were conducted on the ADAV. Equilibrium and kinetic studies play an imperative role in assessing the efficiency of adsorbents. The adsorption isotherms are very useful in determining the maximum quantity $\left(q_{m}\right)$ that can be adsorbed, the pattern of adsorption on the surface of the biomass, the interaction between adsorbate and adsorbent's surface, and whether it is chemisorption or physisorption. On the other hand, the kinetic studies can be used to determine the rate of adsorption, the thickness of the formed layer around the sorbent, and whether the reaction is controlled by diffusion or adsorption mechanisms. The following sections reveal a discussion on the adsorption isotherms as well as the kinetics of the adsorption of TY on ADAV.

\subsubsection{Equilibrium Isotherms}

The adsorption isotherm expresses the specific relationship between the degrees of accumulation on the adsorbent surface and the concentration of sorbate at constant temperature [18]. Four isotherm models were used to investigate the adsorption process of TY on ADAV. These models included Langmuir, Freundlich, Temkin, and Dubinin-Radushkevich (DR) isotherm.

Langmuir isotherm explains the single-layer homogeneous adsorption on a surface, as shown in Figure 9A and Table 6. The basic characteristic of Langmuir equation is shown in Equation (6).

$$
q_{e}=\frac{q_{m} K_{L} C_{e}}{1-K_{L} C_{e}}
$$

where $q_{m}$ is the monolayer adsorption capacity and $K_{L}$ is the Langmuir equilibrium coefficient. In addition, the Langmuir equation can be stated using the dimensionless equation:

$$
R_{L}=\frac{1}{1-K_{L} C_{0}}
$$

where $R_{L}$ is separation factor, and $C_{0}(\mathrm{mg} / \mathrm{L})$ is the initial concentration. Based on previous reports [47,48], the adsorption favorability is dependent on the value of $R_{L}$. In general, if $R_{L}$ is $>1$, the adsorption process is unfavorable, if $R_{L}=1$, adsorption is linear, and with a value between $0-1$, the adsorption is favorable (occurs spontaneously); if the value $=0$, adsorption is irreversible. The calculated $R_{L}$ values in the current investigation were $<1$ and $>0$, implying that the adsorption process was spontaneous with maximum adsorption $\left(q_{\max }\right)=55.25 \mathrm{mg} / \mathrm{g}$. 

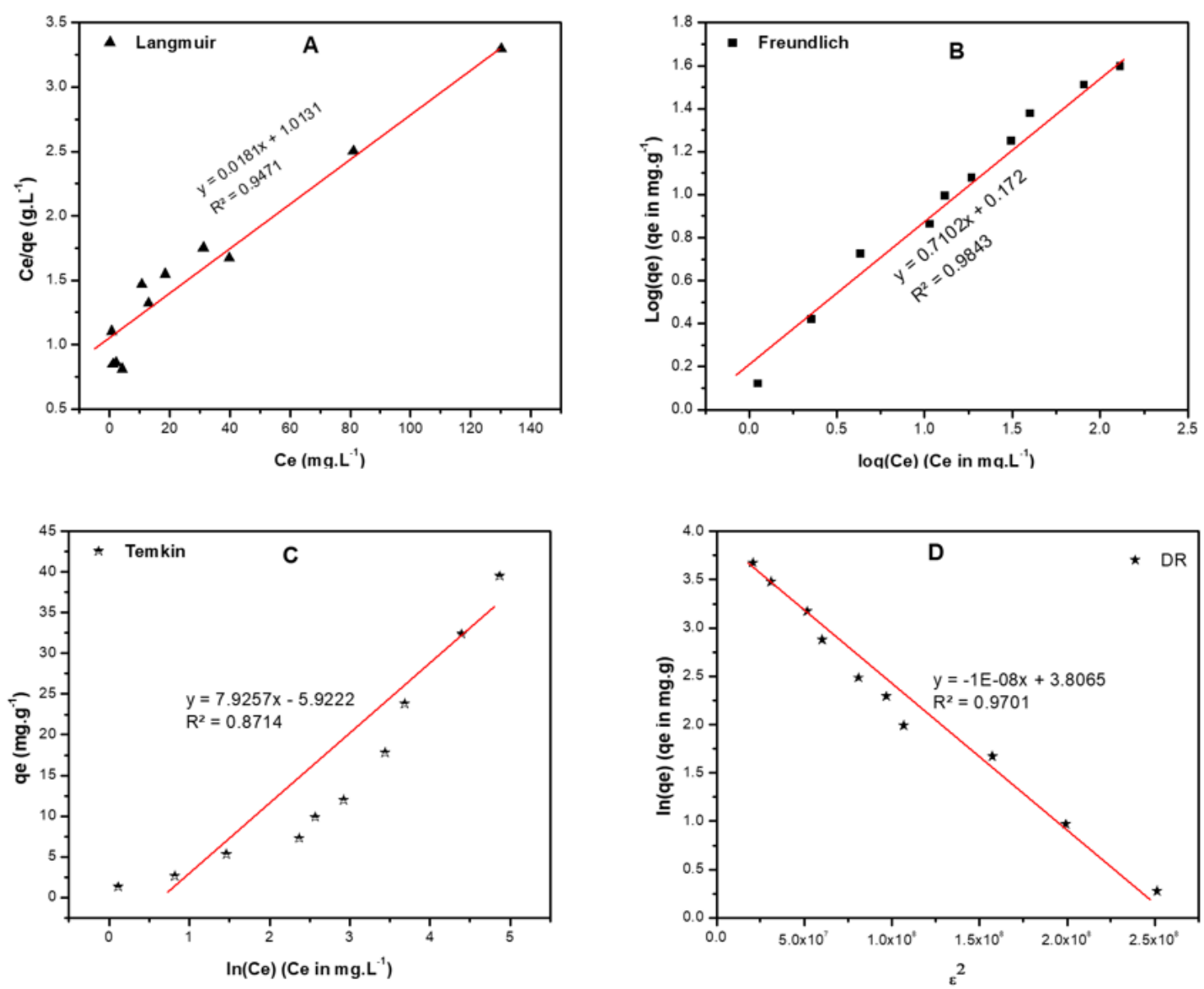

Figure 9. Adsorption isotherms of TY on ADAV including (A) Langmuir, (B) Freundlich, (C) Temkin, and (D) Dubinin-Radushkevich (DR).

Table 6. General and linearized equations of Langmuir, Freudlich, Temkin, and Dubinin-Radushkevich isothems beside their parameters for the adsorption of TY on ADAV.

\begin{tabular}{cccc}
\hline Isotherm & $\begin{array}{c}\text { Equations } \\
\text { (Generalized/Linearized Forms) }\end{array}$ & Parameters & Value \\
\hline \multirow{2}{*}{ Langmuir } & $q_{e}=\frac{q_{m} K_{L} C_{e}}{1-K_{L} C_{e}}$ & $q_{m}(\mathrm{mg} / \mathrm{g})$ & 55.25 \\
& $\frac{C_{e}}{q_{e}}=\frac{1}{q_{m} K_{L}}+\frac{C_{e}}{q_{m}}$ & $K_{L}\left(\mathrm{~L} \cdot \mathrm{mole}^{-1}\right)$ & 0.017 \\
\hline \multirow{2}{*}{ Freundlich } & $q_{e}=K_{F} C_{e}^{\frac{1}{n}}$ & $\frac{1}{n}$ & 0.947 \\
& $\log \left(q_{e}\right)=\log \left(K_{F}\right)+\left(\frac{1}{n}\right) \log \left(C_{e}\right)$ & $(\mathrm{mole} / \mathrm{g})(\mathrm{L} / \mathrm{mole})^{1 / \mathrm{n}}$ & 1.486 \\
& $q_{e}=\frac{R T}{b_{T}} \ln \left(A_{T} C_{e}\right)$ & $\mathrm{R}^{2}$ & 0.984 \\
\hline \multirow{2}{*}{ Temkin } & $q_{e}=\frac{R T}{b_{T}} \ln \left(A_{T}\right)+\frac{R T}{b_{T}} \ln \left(C_{e}\right)$ & $A_{T}(\mathrm{~J} / \mathrm{mole})$ & 311.014 \\
& $\ln \left(q_{e}\right)=\ln \left(q_{m}\right)-\beta \epsilon^{2}$ & $\mathrm{R}^{2}$ & 0.473 \\
DR & $\epsilon=R T\left(1+\frac{1}{C_{e}}\right)$ & $E(\mathrm{~kJ} / \mathrm{mole})$ & 0.8714 \\
\hline & $E=\frac{1}{\sqrt{2 \beta}}$ & $q_{s}(\mathrm{mg} / \mathrm{g})$ & $1 \times 10^{-8}$ \\
& & $\mathrm{R}^{2}$ & 7.07 \\
&
\end{tabular}

The Freundlich isotherm used to describe heterogeneous surface energies is given by the equation:

$$
q_{e}=K_{F} C_{e}^{\frac{1}{n}}
$$


Here, the $C_{e}$ is the equilibrium concentration of TY $\left(\mathrm{mg} \cdot \mathrm{L}^{-1}\right), q_{e}$ is the amount of TY adsorbed/unit mass $\left(\mathrm{mg} \cdot \mathrm{g}^{-1}\right)$, and $K_{F}\left(\right.$ mole $\left.\cdot \mathrm{g}^{-1}\right)\left(\mathrm{L} \cdot \mathrm{mole}^{-1}\right)^{1 / \mathrm{n}}$ and $1 / \mathrm{n}$ are Freundlich coefficients (Figure $9 \mathrm{~B}$ and Table 6). The Freundlich plot (Figure 9B) showed a good fit with a coefficient of determination, $\mathrm{R}^{2}=0.9843$ with $1 / \mathrm{n}=0.71$ and $\mathrm{n}=1.487$. Therefore, the adsorption potential $(\mathrm{A}=\mathrm{nRT})=4.12 \mathrm{~kJ}$, thus any TY with a potential energy less than $4.12 \mathrm{~kJ}$ would be adsorbed on the surface of ADAV, and reactions would tend to be irreversible and favorable. These data confirm that the Freundlich isotherm was more applicable to study the adsorption process of TY on ADAV.

The Temkin isotherm (Figure 9C) gives an idea about the adsorbate-adsorbent interaction by the factor that describes the fact that the heat of adsorption of all the molecules in the layer decreases linearly with the adsorbent-adsorbate interactions. The data shown in Table 6 shows that the $\mathrm{R}^{2}$ value was 0.8714 , signifying that this isotherm was not applicable in this study.

Finally, the DR isotherm (Figure 9D) is usually applied to differentiate between the adsorption mechanisms on a heterogeneous surface. The physical adsorption occurred when the free energy was $<8.0 \mathrm{~kJ} / \mathrm{mol}$, while the chemical adsorption occurred when the free energy was $>8.0 \mathrm{~kJ} / \mathrm{mol}$. The free energy for adsorption of TY on ADAV was physical, as shown in Table 6, where the E equals $7.07 \mathrm{KJ}$.

\subsubsection{Kinetic Studies}

Four kinetics models, namely, pseudo-first order (PFO), pseudo-second order (PSO), Elovich, and Weber-Morris, were applied to simulate the kinetics of the adsorption of TY onto ADAV. Figure 10A,B show the plots of $\ln \left(q_{e}-q_{t}\right)$ and the time $/ q_{t}$ vs time for the PFO and the PSO kinetic models, respectively. The calculated parameters of the two models are listed in Table 7. By comparing the coefficient of determination values $\left(\mathrm{R}^{2}\right)$ of the two models, it could be concluded that the experimental data were in good agreement with the PSO model $\left(R^{2}=0.993\right)[49,50]$. Therefore, the reaction is represented as follows:

$$
T Y+A D A V(\stackrel{k}{\rightarrow})\{T Y-A D A V\}
$$
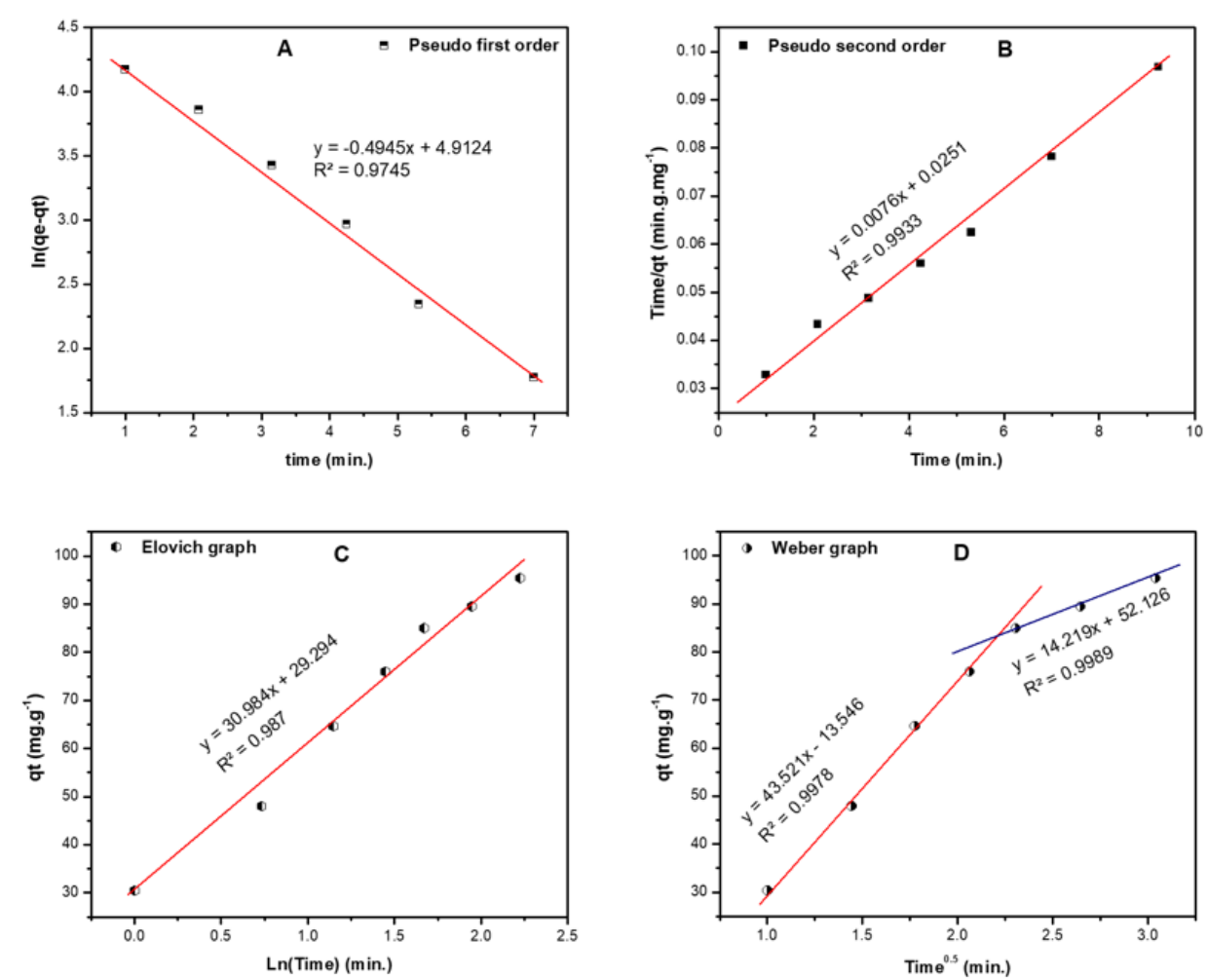

Figure 10. (A) First order, (B) second order, (C) Elovich, and (D) intra-particle diffusion (Weber) curves of adsorption of TY on ADAV. 
Table 7. The kinetics study results corresponding to Figure 10.

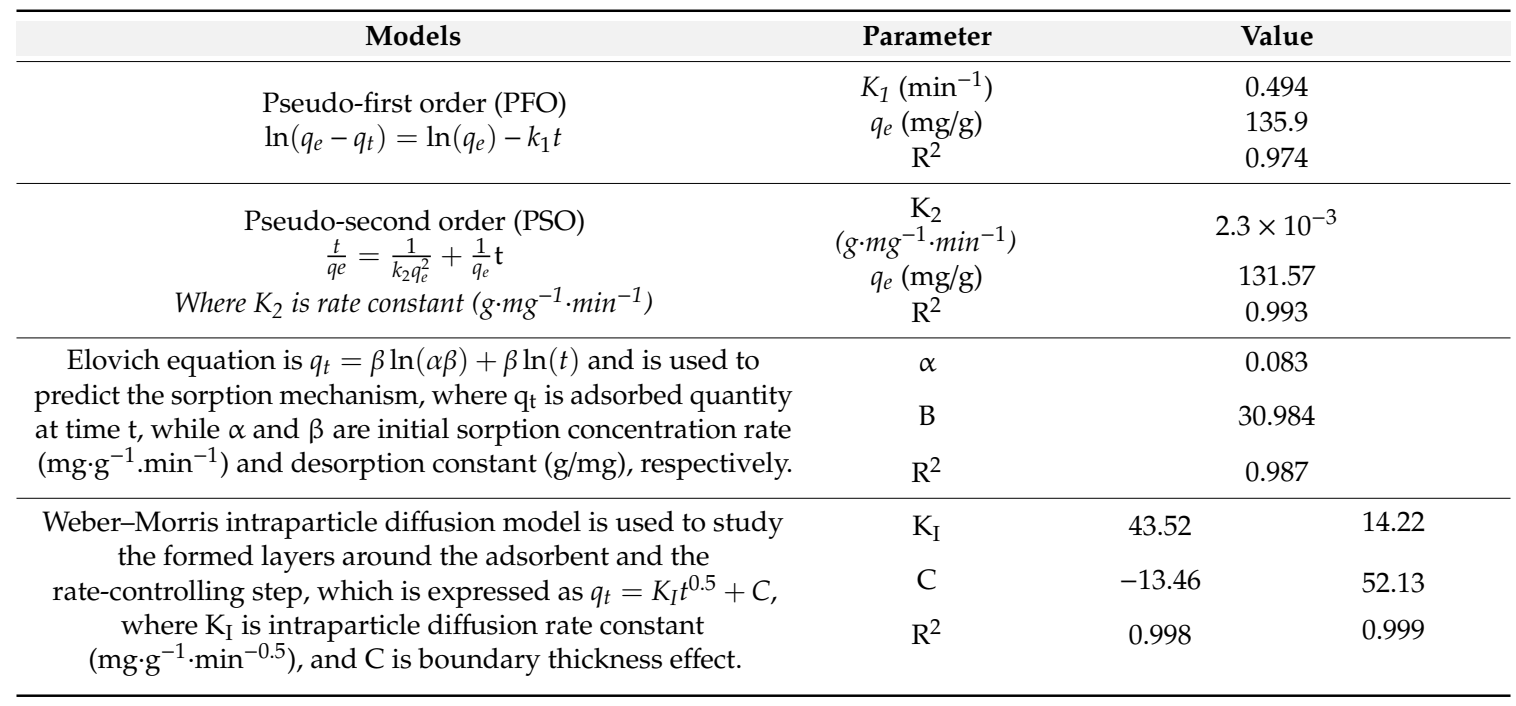

Consequently, the rate of the reaction equaled $k[T Y][A D A V]$, indicating that the adsorption rate depended on both the adsorbate and the adsorbent.

According to the Elovich model shown in Figure 10C, the high $\mathrm{R}^{2}$ values (0.987) show that the desorption rate was higher than the initial sorption. From the Weber-Morris intraparticle diffusion model (Figure 10D), it is clear that there were two regions; the first region had almost no boundary layer, the diffusion rate was very fast, and the negative sign indicated the penetration of TY to the surface of ADAV. After a while, a TY layer formed around the particles, preventing further penetration of TY with a boundary layer equal to $52.13 \mathrm{mg} / \mathrm{g}$, which was close to the $q_{\max }$ calculated by the Langmuir isotherm. Therefore, the reaction in the beginning was controlled by diffusion but later on by adsorption.

\section{Conclusions}

As per the introduced data, Aloe vera (AV) leaves could be recycled into a low-cost, non-conventional green adsorbent. The removal efficiency as well as the adsorption capacity of ADAV proved to be better compared to the thermally treated samples (TTAV). Optimization of the adsorption process was done using a contemporary approach (PBD). Two responses (\%R and $\left.q_{e}\right)$ were measured as functions of four variables ( $\mathrm{pH}, \mathrm{AD}, \mathrm{DC}$, and $\mathrm{ST}$ ). The target was set to maximize both responses. Two mathematical models were therefore developed to predict the removal efficiency and the adsorption capacity. As per the regression models, increasing the concentration of TY enhanced both responses, contrary to $\mathrm{pH}$ and ST. Moreover, while the sorbent dosage had a positive impact on the $\% \mathrm{R}$, it had a negative influence on $q_{e}$.

$\mathrm{CHN}$ analysis showed that the carbon content increased significantly with the thermal treatment from $35.8 \%$ to $52.7 \%$. Increasing of the carbon content was proven by using EDX analysis. Raman spectra showed the conversion of ADAV into a carbonaceous material similar to graphene oxide, which was also confirmed by FT-IR, which showed the disappearance of $\mathrm{O}-\mathrm{H}$ and $\mathrm{C}-\mathrm{H}$ groups and the presence of the $\mathrm{C}=\mathrm{O}$ in TTAV300. SEM micrographs showed a formation of porous material by thermal treatment.

Equilibrium studies revealed that the adsorption of TY on ADAV was well described by the Freundlich isotherm, where $\mathrm{n}>1$, and the adsorption was favorable. The maximum adsorbed quantity $=55.25 \mathrm{mg} / \mathrm{g}$, as calculated by Langmuir isotherm. Moreover, the calculated adsorption energy $(7.07 \mathrm{KJ})$ by the Dubinin-Radushkevich isotherm signified that the adsorption occurred through physisorption. The kinetic study revealed that the reaction was second order reaction and was controlled at the beginning by a diffusion reaction followed by adsorption when the boundary layer $=52 \mathrm{mg} / \mathrm{g}$.

Author Contributions: Conceptualization, M.E.-A.; Data curation, M.E.-A., S.N.D.; Formal analysis, M.E.-A., A.S.E.-S. and A.A.I.; Funding acquisition, M.E.-A.; Investigation, S.N.D.; Methodology, M.E.-A.; Project 
administration, M.E.-A.; Resources, A.A.I.; Software, M.E.-A.; Supervision, M.E.-A.; Validation, M.E.-A., A.S.E.-S.; Visualization, M.E.-A.; Writing—original draft, M.E.-A.; Writing-review \& editing, M.E.-A., A.S.E.-S. and A.A.I.

Funding: This work was made possible by Qatar University Internal Student Grant [QUST-2-CAS-2019-18] from Qatar University. The statements made herein are solely the responsibility of the authors. The publication of this article was funded by the Qatar National Library.

Acknowledgments: The project members would like to extend their special thanks to the Central Lab Unit (CLU) at the Qatar University.

Conflicts of Interest: The authors declare no conflict of interest.

\section{References}

1. Enoh, B.S.; Christopher, W. Adsorption of metal ions from carwash wastewater by phosphoric acid modified clay: Kinetics and thermodynamic studies. J. Chem. Mater. Res. 2015, 7, 1-9.

2. Owa, F.D. Water Pollution: Sources, Effects, Control and Management. Med. J. Soc. Sci. 2013, 4, 58-65. [CrossRef]

3. De Gisi, S.; Lofrano, G.; Grassi, M.; Notarnicola, M. Characteristics and adsorption capacities of low-cost sorbents for wastewater treatment: A review. Sustain. Mater. Technol. 2016, 9, 10-40. [CrossRef]

4. Banat, I.M.; Nigam, P.; Singh, D.; Marchant, R. Microbial decolorization of textile-dyecontaining effluents: A review. Bioresour. Technol. 1996, 58, 217-227. [CrossRef]

5. Easton, J. The dye maker's view. In Color in Dyehouse Effluent; Cooper, P., Ed.; Society of Dyers and Colourists: Bradford, UK, 1995; pp. 9-21.

6. Robinson, T.; McMullan, G.; Marchant, R.; Nigam, P. Remediation of dyes in textile effluent: A critical review on current treatment technologies with a proposed alternative. Bioresour. Technol. 2001, 77, 247-255. [CrossRef]

7. Pearce, C.I.; Lloyd, J.R.; Guthrie, J.T. The removal of colour from textile wastewater using whole bacterial cells: A review. Dyes Pigments 2003, 58, 179-196. [CrossRef]

8. McMullan, G.; Meehan, C.; Conneely, A.; Kirby, N.; Robinson, T.; Nigam, P.; Banat, I.M.; Marchant, R.; Smyth, W.F. Microbial decolourisation and degradation of textile dyes. Appl. Microbiol. Biotechnol. 2001, 56, 81-87. [CrossRef]

9. Bowling, M.C.; Wertlake, P.T. Selective staining of magnesium by titan yellow applied to incinerated tissue sections. Stain Technol. 1966, 41, 329-331. [CrossRef]

10. Narayanan, A.L.; Dhamodaran, M.; Solomon, J.S. Thermodynamics and kinetics of adsorption of azo dye titan yellow from aqueous solutions on natural plant material Saccharum spontaneum. Pharma Chem. 2015, 7 , $36-45$.

11. Rangabhashiyam, S.; Anu, N.; Selvaraju, N. Sequestration of dye from textile industry wastewater using agricultural waste products as adsorbents. J. Environ. Chem. Eng. 2013, 1, 629-641. [CrossRef]

12. Blackburn, R.S. Natural polysaccharides and their interactions with dye molecules: Applications in effluent treatment. Environ. Sci. Technol. 2004, 38, 4905-4909. [CrossRef] [PubMed]

13. Crini, G. Non-conventional low-cost adsorbents for dye removal: A review. Bioresour. Technol. 2006, 97, 1061-1085. [CrossRef] [PubMed]

14. El-Azazy, M.; El-Shafie, A.S.; Issa, A.A.; Al-Sulaiti, M.; Al-Yafie, J.; Shomar, B.; Al-Saad, K. Potato peels as an adsorbent for heavy metals from aqueous solutions: Eco-structuring of a green adsorbent operating Plackett-Burman design. J. Chem. 2019, 2019, 4926240. [CrossRef]

15. El-Azazy, M.; Kalla, R.N.; Issa, A.A.; Al-Sulaiti, M.; El-Shafie, A.S.; Shomar, B.; Al-Saad, K. Pomegranate peels as versatile adsorbents for water purification: Application of Box-Behnken design as a methodological optimization approach. Environ. Prog. Sustain. Energy 2019. [CrossRef]

16. Al-Saad, K.; El-Azazy, M.; Issa, A.A.; Al-Yafei, A.; El-Shafie, A.S.; Al-Sulaiti, M.; Shomar, B. Recycling of date pits into a green adsorbent for removal of heavy metals: A fractional factorial design-based approach. Front. Chem. 2019, 7, 552. [CrossRef] [PubMed]

17. Kadirvelu, K.; Kavipriya, M.; Karthika, C.; Radhika, M.; Vennilamani, N.; Pattabhi, S. Utilization of various agricultural wastes for activated carbon preparation and application for the removal of dyes and metal ions from aqueous solutions. Bioresour. Technol. 2003, 87, 129-132. [CrossRef] 
18. Gao, B.; Yap, P.S.; Lim, T.M.; Lim, T.T. Adsorption-photocatalytic degradation of Acid Red 88 by supported $\mathrm{TiO}_{2}$ : Effect of activated carbon support and aqueous anions. Chem. Eng. J. 2011, 171, 1098-1107. [CrossRef]

19. David, N.; Hon, S. Chemical Modification of Lignocellulosic Materials, 1st ed.; CRC Press: Boca Raton, FL, USA, 1995; pp. 97-128.

20. Flavio, A.P.; Mazzocato, A.C.; Gushikem, Y. Removal of methylene blue dye from aqueous solutions by adsorption using yellow passion fruit peel as adsorbent. Bioresour. Technol. 2008, 99, 3162-3165.

21. Hamzeh, Y.; Ashori, A.; Azadeh, E.; Abdulkhani, A. Removal of acid orange 7 and remazol black 5 reactive dyes from aqueous solutions using a novel biosorbent. Mater. Sci. Eng. C 2012, 32, 1394-1400. [CrossRef]

22. Mattson, J.S.; Mark, H.B. Activated Carbon: Surface Chemistry and Adsorption from Solution; M. Dekker: New York, NY, USA, 1971.

23. Diao, Y.; Walawender, W.P.; Fan, L.T. Activated carbons prepared from phosphoric acid activation of grain sorghum. Bioresour. Technol. 2002, 81, 45-52. [CrossRef]

24. E-González, M.P.; H-Montoya, V. Removal of acid orange 7 by guava seed carbon: A four parameter optimization study. J. Hazard. Mater. 2009, 168, 515-522. [CrossRef] [PubMed]

25. Agarwal, S.; Tyagi, I.; Gupta, V.K.; Mashhadi, S.; Ghasemi, M. Kinetics and thermodynamics of Malachite Green dye removal from aqueous phase using iron nanoparticles loaded on ash. J. Mol. Liq. 2016, 223, 1340-1347. [CrossRef]

26. Stan, M.; Lung, I.; Soran, M.-L.; Leostean, C.; Popa, A.; Stefan, M.; Lazar, M.D.; Opris, O.; Silipas, T.-D.; Porav, A.S. Removal of antibiotics from aqueous solutions by green synthesized magnetite nanoparticles with selected agro-waste extracts. Process Saf. Environ. Prot. 2017, 107, 357-372. [CrossRef]

27. SFGATE. Available online: https://homeguides.sfgate.com/aloe-tropical-plant-67510.html (accessed on 10 October 2019).

28. Hanafiah, M.A.K.M.; Jamaludin, S.Z.M.; Khalid, K.; Ibrahim, S. Methylene blue adsorption on Aloe vera rind powder: Kinetics, Isotherm and Mechanisms. Nat. Environ. Pollut. Technol. 2018, 17, 1055-1064.

29. Giannakoudakis, D.A.; Hosseini-Bandegharaei, A.; Tsafrakidou, P.; Triantafyllidis, K.S.; Kornaros, M.; Anastopoulos, I. Aloe vera waste biomass-based adsorbents for the removal of aquatic pollutants: A review. J. Environ. Manag. 2018, 227, 354-364. [CrossRef] [PubMed]

30. Malik, R.; Lata, S.; Singhal, S. Removal of heavy metal from wastewater by the use of modified aloe vera leaf powder. Int. J. Basic App. Chem. Sci. 2015, 5, 6-17.

31. Khaniabadi, Y.O.; Heydari, R.; Nourmoradi, H.; Basiri, H.; Basiri, H. Low-cost sorbent for the removal of aniline and methyl orange from liquid-phase: Aloe Vera leaves wastes. J. Taiwan Inst. Chem. E 2016, 68, 90-98. [CrossRef]

32. Lee, K.E.; Hanafiah, M.M.; Abdul Halim, A.; Mahmud, M.H. Primary treatment of dye wastewater using Aloe vera-aided aluminium and magnesium hybrid coagulants. Procedia Environ. Sci. 2015, 30, 56-61. [CrossRef]

33. Beigzadeh, P.; Moeinpour, F. Fast and efficient removal of silver (I) from aqueous solutions using Aloe vera shell ash supported $\mathrm{Ni}_{0.5} \mathrm{Zn}_{0.5} \mathrm{Fe}_{2} \mathrm{O}_{4}$ magnetic nanoparticles. Trans. Nonferrous Met. Soc. China 2016, 26, 2238-2246. [CrossRef]

34. Wang, Y.; Zhu, L.; Wang, X.; Zheng, W.; Hao, C.; Jiang, C.; Wu, J. Synthesis of aminated calcium lignosulfonate and its adsorption properties for azo dyes. J. Ind. Eng. Chem. 2018, 61, 321-330. [CrossRef]

35. Salem, M.A.; Salem, I.A.; Hanfy, M.G.; Zaki, A.B. Removal of titan yellow dye from aqueous solution by polyaniline $/ \mathrm{Fe}_{3} \mathrm{O}_{4}$ nanocomposite. Eur. Chem. Bull. 2016, 5, 113-118.

36. Elazazy, M.S. Factorial Design and Machine Learning Strategies: Impacts on Pharmaceutical Analysis. In Spectroscopic Analyses_-Developments and Applications; Sharmin, E., Zafar, F., Eds.; IntechOpen: London, UK, 2017; pp. 213-230.

37. Plackett, R.L.; Burman, J.P. The design of optimum multifactorial experiments. Biometrika 1946, 33, 305-325. [CrossRef]

38. Box, G.E.P.; Cox, D.R. An Analysis of Transformations. J. R. Stat. Soc. B 1964, B26, 211-252. [CrossRef]

39. Antony, J. Design of Experiments for Engineers and Scientists, 1st ed.; Antony, J., Ed.; Elsevier: Amsterdam, The Netherlands, 2003; pp. 6-16.

40. Bruns, R.E.; Scarminio, I.S.; Neto, B.B. Statistical Design-Chemometrics, 1st ed.; Elsevier: Amsterdam, The Netherlands, 2006.

41. Pathak, P.D.; Mandavgane, S.A.; Kulkarni, B.D. Characterizing fruit and vegetable peels as bioadsorbents. Curr. Sci. 2016, 110, 2114-2123. [CrossRef] 
42. Horn, M.M.; Martins, V.C.A.; Plepis, A.M.D. Interaction of anionic collagen with chitosan: Effect on thermal and morphological characteristics. Carbohydr. Polym. 2009, 77, 239-243. [CrossRef]

43. Nejatzadeh-Barandozi, F.; Enferadi, S.T. FT-IR study of the polysaccharides isolated from the skin juice, gel juice, and flower of Aloe vera tissues affected by fertilizer treatment. Org. Med. Chem. Lett. 2012, 2, 33. [CrossRef]

44. Jithendra, P.; Rajam, A.M.; Kalaivani, T.; Mandal, A.B.; Rose, C. Preparation and characterization of aloe vera blended collagen-chitosan composite scaffold for tissue engineering applications. ACS Appl. Mater. Interfaces 2013, 5, 7291-7298. [CrossRef]

45. Stankovich, S.; Dikin, D.A.; Piner, R.D.; Kohlhaas, K.A.; Kleinhammes, A.; Jia, Y.; Wu, Y.; Nguyen, S.T.; Ruoff, R.S. Synthesis of graphene-based nanosheets via chemical reduction of exfoliated graphite oxide. Carbon 2007, 45, 1558-1565. [CrossRef]

46. Childres, I.; Jauregui, L.A.; Park, W.; Cao, H.; Chen, Y.P. Raman spectroscopy of graphene and related materials. In New Developments in Photon and Materials Research, 1st ed.; Jang, J.I., Ed.; Nova Science Publishers: Oxford, UK, 2013; Volume 1, pp. 403-418.

47. Ooi, J.; Lee, L.Y.; Hiew, B.Y.Z.; Thangalazhy-Gopakumar, S.; Lim, S.S.; Gan, S. Assessment of fish scales waste as a low cost and eco-friendly adsorbent for removal of an azo dye: Equilibrium, kinetic and thermodynamic studies. Bioresour. Technol. 2017, 245, 656-664. [CrossRef]

48. Değermenci, G.D.; Değermenci, N.; Ayvaoğlu, V.; Durmaz, E.; Çakır, D.; Akan, E. Adsorption of reactive dyes on lignocellulosic waste; characterization, equilibrium, kinetic and thermodynamic studies. J. Clean. Prod. 2019, 225, 1220-1229.

49. Sarma, G.K.; Khan, A.; El-Toni, A.M.; Rashid, M.H. Shape-tunable CuO-Nd(OH) nanocomposites with excellent adsorption capacity in organic dye removal and regeneration of spent adsorbent to reduce secondary waste. J. Hazard. Mater. 2019, 380, 120838. [CrossRef] [PubMed]

50. Sun, B.; Yuan, Y.; Li, H.; Li, X.; Zhang, C.; Guo, F.; Liu, X.; Wang, K.; Zhao, X.S. Waste-cellulose-derived porous carbon adsorbents for methyl orange removal. Chem. Eng. J. 2019, 371, 55-63. [CrossRef]

(C) 2019 by the authors. Licensee MDPI, Basel, Switzerland. This article is an open access article distributed under the terms and conditions of the Creative Commons Attribution (CC BY) license (http://creativecommons.org/licenses/by/4.0/). 